\title{
Research Paper An economic study of behaviour of market arrivals and prices of onion, garlic and turmeric in selected markets of U.P.
}

DIWAKER NATH SHUKLA AND J. RAI

ABSTRACT : This study has been undertaken with the twin objectives of examining the variability pattern of market arrivals and prices of selected crops (Onion, Garlic and Turmeric) in selected markets (Lucknow and Kanpur) of Uttar Pradesh and analysing the relationship between market arrivals and prices. The study is based on market arrivals and wholesale prices of selected crops collected from Rajya Krishi Utapadan Mandi Parishad, Lucknow (U.P.), Krishi Utapadan Mandi Samiti, Lucknow and Krishi Utapadan Mandi Samiti, Kanpur for the period 2001-2010. The study has shown that the extent of variability in market arrival of onion was lower in Lucknow market but higher in Kanpur market. Its prices variability was lower in Kanpur market and higher in Lucknow market. In case of garlic, the variability in market arrivals and prices was lower in Kanpur market but higher in Lucknow market. In case of turmeric, the variability in market arrivals and prices was lower in Lucknow market but higher in Kanpur market. The study has confirmed the negative relationship between market arrivals prices of onion, garlic and turmeric over the years in all two markets. However, across different months, there have been several instances of positive relationship between market arrivals and prices in Lucknow and Kanpur market.

KEY WORDS : Onion, Garlic, Turmeric Market arrivals, Prices, Variability, Relationship

HOW TO CITE THIS PAPER : Shukla, Diwaker Nath and Rai, J. (2014). An economic study of behaviour of market arrivals and prices of onion, garlic and turmeric in selected markets of U.P. Internat. Res. J. Agric. Eco. \& Stat., 5 (2) : 235-240. 